\title{
Necessity Analysis of School Enterprise Cooperative Held Application-oriented Undergraduate under the Guidance of "The Belt and Road" Strategy-The Case of Chongqing Vocational Institute of Engineering
}

\author{
Liu Tong, Liu Yu, Yang Zhiyong \\ Chongqing Vocational Institute of Engineering \\ No.1 Nanbei Avenue, Bingjiang new town, Jiangjin district, Chongqing, China 402260
}

\begin{abstract}
As the China first advocated national strategy, "The Belt and Road" strategy has profound strategic significance for China's continuous modernization drive. Conforms to the development of the times, China's communication industry invest lots of manpower to participate in the construction of "The Belt and Road" national communications network. Students received vocational education have some deficiencies in the theoretical basis, Chongqing Vocational Institute of Engineering reform actively, explore and train applied undergraduate graduates with ZTE company together to serve the "The Belt and Road" national strategy.
\end{abstract}

Keywords-"The Belt and Road"; school-enterprise cooperative education; Communications technology; Applicationoriented Undergraduate

\section{INTRODUCTION}

As the national strategy promoted by senior leaders in China, "The Belt and Road" can have a profound strategic meaning for our country to implement modernized construction, and stand on the leading position of the world. "The Belt and Road" strategic concept is put forward in accordance with the common demands of countries along the line, and has opened a new window of opportunity for countries along the line to complement each other's advantages, and realize open development; meanwhile, it is also a new platform for international platform. The acceleration of "The Belt and Road" construction is beneficial for promoting the economic prosperity and regional economic cooperation of countries along the line, reinforcing the exchange and mutual reference of different cultures, and promoting the peaceful development of the world; moreover, it is also a noble cause benefiting people all over the world. The important task for communication industry to serve "The Belt and Road" strategy is to reinforce the international communication interconnection level, and smoothen the information silk road.

The communication industry belongs to high-tech industry, which not only requires the employees to have solid theoretical basic knowledge, but also solid practical operation and operation capacity. During the current period, the cultivation direction for undergraduate level places emphasis on tamping

Chongqing 2016 Major projects of teaching reform in Higher Education in "Exploration and practice of multicultural school running system in Higher Vocational Education"; Chongqing 2015 deepening comprehensive pilot projects in the field of Education "Reform of multicultural school running system in Higher Vocational Education"; Teaching reform project of Chongqing Vocational Institute of Engineering "Exploration and practice of modern apprenticeship in ICT major". theoretical foundation, and constructing knowledge hierarchy, while the higher vocational education layer places emphasis on cultivating the students' practical capacity. The two methods have their own strong points, but they also seem to be slightly insufficient. In order to cultivate more excellent graduates to serve the important strategy of "The Belt and Road" of the state both the two layers of cultivation modes shall be appropriately reformed, and the first mode for reform is the transformation of undergraduate colleges towards application-oriented colleges, and the other mode is to carry out application-oriented undergraduate education in higher vocational colleges. "The Belt and Road" strategy can not only provide new opportunity for talent development, but also raise new requirements for talent quality and capacity. The higher vocational colleges must closely follow the trend, constantly improve talent cultivation quality, closely follow the step mode of "The Belt and Road" strategy development, improve the talent cultivation quality, and closely follow the development step of "The Belt and Road" strategy [1].

\section{THE DEMAND OF "THE BELT AND ROAD" STRATEGY FOR TALENTS OF COMMUNICATION INDUSTRY}

\section{A. Current status about "The Belt and Road" in the national communication industry}

Information has become an indispensable and important component of human life, and the degree of dependency for obtaining various kinds of information and the communication of people has also become higher and higher. Due to the continuous improvement of communication technology, the high-speed and high-qualified data service borne as per wired or wireless mode has stepped into the life of common people. 


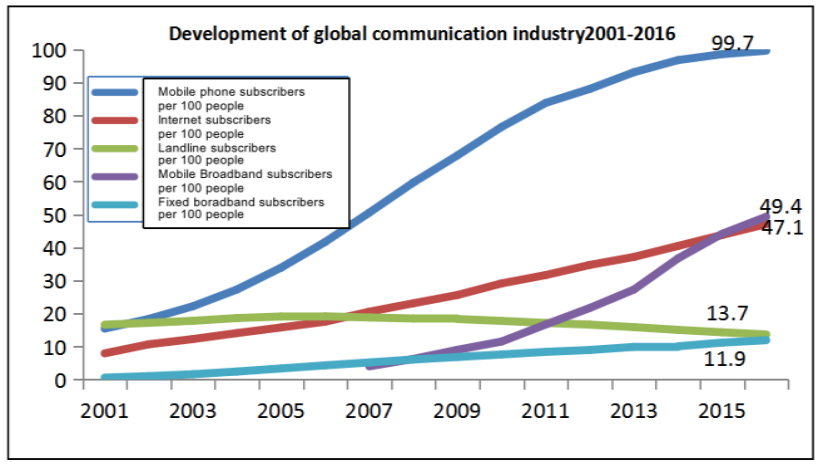

Fig. 1. 2001-2016 Global Communication Industry Development Conditions

As can be seen from the data provided by the International Telecommunications Union, the global communication industry can still keep the fast development momentum, especially for mobile users, Internet users and mobile broadband users, which are all developed at a relatively high speed.

Table 1 is the quantity of users with mobile phone per hundred people within different regions, and as can be seen from the table, the developing countries represented by countries along "The Belt and Road" are now located at a backward position in the global informatization progress, and as for the quantity of users with phones per hundred person in countries along the line in 2016, there were 143.3 phones in the region of the Commonwealth of Independent States, 109.9 phones in Arab Region, and 94.1 phones in Asia-Pacific Region.

As can be seen from the quantity of users using mobile broadband per hundred residents worldwide, in 2016, the quantity of users using mobile broadband per hundred residents for countries along "The Belt and Road" was as follows: there were 53 users in the region of the Commonwealth of Independent States, 47.6 users in Arab Region, and 42.6 users in Asia-Pacific Region, while in developed countries, the quantity had reached to 90.3 , and in developing countries represented by t countries along "The Belt and Road", the popularizing rate about the fixed broadband network was actually less than a half of the total quantity of people; when being compared with developed countries, the communication industry in countries along "The Belt and Road" still has a big development space.
TABLE I. COMPARISON ABOUT THE QUANTITY OF USERS WITH MOBLLE PHONE PER HUNDRED PEOPLE WITHIN DIFFERENT REGIONS IN 2016

\begin{tabular}{|c|c|}
\hline Region & 2016 \\
\hline America & 143.3 \\
\hline Europe & 119.5 \\
\hline $\begin{array}{c}\text { Commonwealth of } \\
\text { Independent States }\end{array}$ & 111.5 \\
\hline Arab States & 109.9 \\
\hline Global & 99.7 \\
\hline Asian-Pacific Region & 94.1 \\
\hline Africa & 80.8 \\
\hline
\end{tabular}

TABLE II. COMPARISON ABOUT THE QUANTITY OF USERS USING MOBILE BROADBAND PER HUNDRED PEOPLE WITHIN DIFFERENT REGIONS IN 2016

\begin{tabular}{|c|c|}
\hline Region & 2016 \\
\hline America & 78.2 \\
\hline Europe & 76.6 \\
\hline $\begin{array}{c}\text { Commonwealth of } \\
\text { Independent States }\end{array}$ & 53 \\
\hline Arab States & 49.4 \\
\hline Global & 47.6 \\
\hline Asian-Pacific Region & 42.6 \\
\hline Africa & 29.3 \\
\hline
\end{tabular}

B. Analysis on the demand of "The Belt and Road" strategy for talents of communications industry

The acceleration of "The Belt and Road" construction can be beneficial for promoting the economic prosperity and regional economic cooperation of countries along the line, reinforce different cultural exchanges and mutual references, and promote the peaceful development of the world; moreover, it is also a noble cause benefiting people all over the world. The important task for communication industry to serve "The Belt and Road" strategy is to reinforce the international communication interconnection level, and smoothen the information silk road.

In the field of mobile communication, the three operators have fulfilled their missions, and exerted forces jointly. By virtue of GTI platform, China Mobile has promoted 53 countries and regions worldwide to deploy 99 TD-LTE networks, of which 21 countries and regions along "The Belt and Road" constructed 39 TD-LTE networks; as for China Unicom, it has been engaged in the layout of smart network through actively exploring $5 \mathrm{G}$ technology, accelerating the deployment of the internet of things, and promoting SDN/NFV network transformation. With respect to the fixed network, the three operators have led and participated in the construction of land and submarine optical cable connecting Asia and Africa continents, and meanwhile, provided information express interconnection guarantee for "The Belt and Road" construction. 
Along "The Belt and Road", there are 64 countries, occupying $2 / 3$ of the total population worldwide, and $1 / 3$ of the economic scale worldwide; commonly, they belong to the rising stage of economic development, and the acceleration stage of infrastructure construction; moreover, the fast development of the society has put forward a higher requirement for the quantity of talents in communication industry.

\section{THE DEMAND OF REGIONAL ECONOMIC DEVELOPMENT FOR COMMUNICATIONS INDUSTRY TALENTS}

\section{A. Overview to the development of communications industry in our country}

Our country is now under the important period of economic structural adjustment, and the construction of "high-speed smoothness, urban and rural coverage, good quality and favorable price as well as convenient service" broadband network will effectively drive investment demand and information consumption, support "Internet+" action plan, promote industrial, informationization, new urbanization and rural modernization, and arouse overall economic vigor.

Along with the accelerated promotion of informatization process in our country as well as the in-depth implement of "Internet+", the high data transmission business represented by video-on-demand, online video, IPTV, etc. have been popularized, and the new communication technologies represented by the Internet of Things, the cloud calculation, smart city, etc. have also started to step into the application field. These new businesses put forward the updating and dilatation requirements for the transmission network, and request the communication operators to provide high-speed ports with higher density and stronger multicast capacity, so as to cope with the data transmission submit demand.

In 2016, the net increase in the quantity of users implementing fixed internet broadband access in these three basic telecommunications enterprises was 37.74 million households, and the total number reached to 297 million households. The urban construction of broadband continuously promoted the popularity of optical access, and the net increase in the quantity of users implementing optical access (FTTH/FTTO) was 79.41 million households, and the total quantity reached to 228 million households. In the same year, the quantity of $4 \mathrm{G}$ users presented explosive increase, and 340 million households were newly increased in the full year, and the total quantity reached to 770 million households; the net increase in the quantity of users using phones was 26.17 million households worldwide, and the total quantity reached to 1.53 billion households, which was increased by $1.7 \%$ on a year-on-year basis, of which the net increase in the quantity of users using mobile phones was 50.54 million households, and the total quantity reached to 1.32 billion households; the popularizing rate of mobile phone users reached to 96.2 phones/hundred people, which was increased by 3.7 phones/hundred people, when being compared with last year[2].
The research has showed that, higher vocational college is the supply subject for high-skilled talents of information technology industry. During the period of "the 12th Five Year Plan", there were totally 1.6784 million students graduated from electronic information major of higher vocational colleges, occupying $10.43 \%$ of the total number of graduates. Under the background of the new round of information technology reform, the new generation of information technology industry has put forward new challenges for the capacity of high-skilled talents, and the high-skilled talent information technology has become the important theory and practical issue faced in the modernized vocational education development [3].

\section{B. The urgent demand for Chongqing to create the highland strategy of information industry}

As the only direct-controlled municipality in the central and western regions of our country, Chongqing has outstanding regional advantages, and important strategic position; it is the important strategy support for the west development, and is located at the junction point for "The Belt and Road" and Yangtze River Economic Zone, and can exert an unique and important function in the regional development of the state and the opening-up pattern. In the Information Industry Development Plan jointly published by MIIT and NDRC, it has clearly expressed the support for the Midwest Area to set foot on its own advantages, and undertake the industrial transfer; meanwhile, it has also encouraged the central cities with better industrial base in the west area to improve the R\&D capacity and industrial layer, and promote the industrial region pattern integrating the division of labor for the east-central-west regions and complementary advantages.

"Internet+" strategy has provided historical opportunities for the transformation and upgrading of traditional industry and the integration of internet; Chongqing "13th Five Year" Plan requests the vigorous development of information technology service oriented to the manufacturing industry, the active promotion of widely applying internet, cloud calculation, big data, the internet of things, etc. in the manufacturing industry. As the basis and subject of "Internet+", talents are the origin of force for balancing "stable growth and structural adjustment", and the construction of "Internet + " talents in the information communication industry is the key issue unavoidable for developing internet economy.

In 2016, Chongqing Communication Administration investigated the basic condition about the talents of information communication industry in Chongqing City, the talent structure, talent demand, and talent cultivation mode, etc., and meanwhile, published the White Paper about the "Internet+" Talents of Information Communication Industry in Chongqing City in March, 2017, and the White Paper has pointed out that the talent educational background structure for information communication industry of Chongqing City shall be further optimized, and it is in lack of highly educated talents. 


\section{DEEPEN MiXed OWNERSHIP REForM, AND PROMOTE THE DEMAND OF SCIENTIFIC DEVELOPMENT IN SCHOOLS}

A. The demand for deepening the mixed ownership schoolrunning reform between the school and ZTE Corporation

The exploration on developing mixed ownership vocational colleges can be beneficial for promoting the state-owned education capital in enlarging the efficiency, arising various social active factors to participate in vocational education development, attracting various ownership capitals to enter into the field of technical skill talent cultivation, and forming modernized vocational education school-running mode and school management mechanism with multiple investments, diversified property rights, autonomous, efficient, standard and self-disciplined properties. Chongqing Vocational Institute of Engineering and ZTE Corporation choose "mobile communication technology", and "cloud calculation technology and application" as the cooperation major, jointly establish "ZTE Communication Information College", jointly carry out school-enterprise cooperation in talent cultivation, jointly study "school-enterprise" integrated talent cultivation mode [4], and carry out the new mode of mixed ownership talent cultivation, which can realize seamless connection with the industry.

"ZTE Communication Information College" has introduced enterprise teacher forces and advanced teaching management mode, and has obtained relatively big progress in the cooperation with schools in erecting training platform, building course standard, constructing evaluation system, implementing teaching task, developing informationization platform, constructing teaching team, studying teaching management system and other aspects. On the basis that "ZTE Communication Information College" established by Chongqing Vocational Institute of Engineering and ZTE Corporation through mixed ownership reform has successfully held the joint cultivation of higher vocational specialties, the two parties have reached consensus considering further deepening the mixed ownership reform, and jointly cultivating the application-oriented undergraduate talents requested for ZTE "The Belt and Road" construction: as per the actual demand of enterprises for talents, the implementation of different layers of application-oriented talent cultivation can be beneficial for forming sound students' professional management system, and promoting the development of students' vocational capacity; meanwhile, it is also beneficial for forming sound vocational training system, and reinforcing the training capacity of colleges for enterprise personnel; furthermore, it can also be beneficial for forming sound application-oriented talent supply chain, and deepening the talent cultivation cooperation relationship with enterprises.

\section{B. The demand of talent distribution in communication enterprises}

Currently, application-oriented undergraduate reform can be mainly divided into two approaches, i.e., the transformation of common undergraduate colleges and the quality improvement of higher vocational colleges. The talents cultivated through the application-oriented undergraduate opened after the transformation of common undergraduate colleges are mainly oriented to product $\mathrm{R} \& \mathrm{D}$ type, product sales type, project management type, network planning type and other posts, and these posts have a higher demand for theoretical knowledge and the mastering degree about the overall situation of network; the application-oriented undergraduate opened by higher vocational colleges that cultivate technology and skill oriented application talents can be closer to the first-line production service, and the students cultivated thereby can be directly engaged in engineering delivery, network maintenance, network optimization, overseas after-sales support, etc.

Huawei, ZTE and other famous communication companies have hundreds of thousands of employees. Such large-scaled companies will always emphasize on the $R \& D$ of proprietary intellectual property rights; although they emphasize on the recruitment of research-oriented talents, the characteristics of communication industry have also made it necessary for them to have more demands for first-line application-oriented technical talents. Through analyzing as per the current talent supply side conditions, students of higher vocational colleges are still lack in theoretical basis knowledge reserves, while the undergraduates are also slightly insufficient in technical skill application [5]. Thus, in order to solve the human resource dilemma for communication enterprises represented by ZTE, it is extremely necessary to hold communication engineering application-oriented undergraduate colleges.

\section{The demand of "The Belt and Road" development strategy in modernized vocational education service}

"The Belt and Road" strategy has broken through the existing pattern of national economic development, deeply integrated the supply chain, industrial chain, and value chain, and newly built the international economy layout. In the 64 countries along "The Belt and Road", most of them are emerging economic entities, and this has increased new growth points and new routes of Chinese economy for the opening-up in China [6].

By virtue of high-qualified, and low-price product advantages, more and more Chinese communication enterprises are quite popular among countries along "The Belt and Road", and behind the booming market, it is the demand of enterprises for more excellent talents of communication major. Currently, there are three modes for cultivating such internationalization talents, i.e., cultivating domestic students and transporting them to the abroad, establishing international colleges at abroad as well as recruiting and cultivating overseas students.

In the aforementioned three modes, "the overseas establishment of international colleges" and "the recruitment and cultivation of overseas students" can meet the urgent 
demand of the local for communication technology talent localization, decrease enterprise labor cost, and meanwhile, transmit the excellent culture in China. Chongqing Vocational Institute of Engineering has actively explored the mode to "let the vocational education go out", constructed CEC (College Enterprise Country or College) school-running mode, and has not only united ZTE and overseas colleges in establishing "International Silk Road College", but also used qualified education resources to attract overseas students to study in China.

"The Belt and Road" strategy has put forward an extremely big challenge for the existing course system and course contents in vocational colleges. As per the existing policies of the state, the time for students to study at vocational colleges is three year, but it is impossible for schools to open more international course tasks within the short three years, so it is necessary to hold application-oriented undergraduate colleges to perfect the course system, and cultivate the communication engineering internationalization application-oriented talents meeting "The Belt and Road" demand.

\section{SUMMARY}

The development of regional economy, the development of the state and the development of the world require qualified communication facilities as the guarantee, and in order to better serve "The Belt and Road" national strategy, and provide talent guarantee for the communication industry of our country to go out of the country and walk towards the world, it is imperative for Chongqing Vocational Institute of Engineering to cooperate with ZTE Corporation in jointly cultivating applicationoriented undergraduate courses of communication major.

\section{REFERENCES}

[1] Chen Xiangfen. Research about the Collaborative Innovation Talent Cultivation Mode of Higher Vocational Colleges under the Background of "The Belt and Road" [J]. Chinese Vocational and Technical Education, 2016(4): 42-45.

[2] Statistical Bulletin about the Communication Operation Industry in 2016 [R]. MIIT, 2017.01.

[3] Xu Yanli, and Fan Ningning. The Core Capacity Construction and Cultivation Approach for the New Generation of Highly Skilled Talents in Information Technology Industry $[\mathrm{J}]$. Vocational \& Technical Education Forum, 2017, (21): 5-9.

[4] Lin Chengwen. The Practice of School-enterprise Integration" Talent Cultivation Mode for Mobile Communication Technology Major in Higher Vocational Colleges [J]. Vocational and Technical Education, 2015, 36 (35): 16-19.

[5] Yang Yong, and Sun Shuping. Employment Quality Investigation and Improvement Strategy for Graduates of Information Type Higher Vocational Colleges [J]. Vocational and Technical Education, 2016, 37 (29): 54-57.

[6] Zhu Lei. Research on the Innovation of Route for Higher Vocational Colleges to Help Enterprises "Go out" under the Strategic Background of "The Belt and Road" [J].Chinese Vocational and Technical Education, 2016 (33): 106-110 